\title{
19- Orhun Yazıtları'nda geçen atasözleri ve deyimlerin verdiği mesajların dil ve kültür birlikteliği açısından değerlendirilmesi ${ }^{1}$
}

\section{Yüksel GÍRGIN}

APA: Girgin, Y. (2021). Orhun Yazıtları’nda geçen atasözleri ve deyimlerin verdiği mesajların dil ve kültür birlikteliği açısından değerlendirilmesi. RumeliDE Dil ve Edebiyat Araştırmaları Dergisi, (25), 308-322. DOI: 10.2900o/rumelide.1036536.

\section{$\ddot{O} \mathbf{z}$}

Türk dilinin yaşını belirlemede hareket noktasını oluşturan ve önemli bir belge niteliği taşıyan Orhun Yazıtları, Türkçenin bilinen ilk yazılı kaynaklarıdır. Sosyal psikoloji kapsamında bakıldığında dil, bir milletin en önemli kültür varlığıdır. Dilin sosyolojik varlı̆̆ı içerisinde önemli bir yere sahip olan deyimler ve atasözleri, bir toplumun dünya görüşünü de yansıtmaktadır. Dil ve kültür birlikteliği, sosyolojik mânâda bir topluma millet olma vasfını kazandıran en önemli yapı taşıdır. Toplumların duygu ve düşünce dünyalarını kuşatmakla kalmaz aynı zamanda diğer toplumlar karşısında varlığını korumada da önemli rol oynar. Yazıtlarda geçen atı küsi yok bol- "adı sanı yok olmak”, ot sub kıl"ateş ile su gibi birbirine düşman etmek”, uça bar- "uçup gitmek, ölmek”, adak kamşat- "gerçek anlamda ayağı burkmak, mecaz anlamda şaşırıp yanlış hareket etmek” gibi deyimlerin Türkçenin söz varlığı kapsamında anlatımı güçlendirmede etkin rol oynadıkları görülmektedir. Yazıtlarda geçen sözcük sayısı (Kültigin, Bilge Kağan ve Tonyukuk yazıtlarında) takriben 6.ooo, farklı anlamda kullanılan sözcüklerin sayısı ise 840 civarındadır. Nitel araştırma yaklaşımının benimsendiği çalışmada veriler doküman analizi tekniğiyle elde edilmiştir. Orhun Yazıtları'nda geçen atasözleri ve deyimlerin hitabet, ifade becerisi, soyut kavramları karşılama gücü bakımından derinlikli arka planı dikkate alındığında Türkçenin çok uzun zaman önce olgunlaşmış bir dil hüviyeti kazandığı görülmektedir. Bu durum Orhun Yazıtları'na tarihî seyir içerisinde Türk toplumunun millet olma yolunda katettiği mesafenin en önemli belge niteliğini kazandırmaktadır.

Anahtar kelimeler: Orhun Yazıtları, Türkçenin söz varlı̆̆ı, deyimler, atasözleri

\section{Evaluating the messages of the proverbs and idioms in Orhon Inscriptions in regards to language and culture synergy}

\begin{abstract}
Orhon Inscriptions (also spelled as Orkhon), the significant writings that constitute the starting point in determining the history of the Turkish language, are the first known written sources in Turkish. Language is the most important cultural asset of a nation in terms of social psychology. Idioms and proverbs, which have an important place in the sociological existence of a language, also reflect the world view of a society. In the sociological sense, the synergy between language and culture is the most important building block that creates a nation from a society. This synergy does not only affect the sentiments and thoughts of societies, but also plays a crucial role in preserving their existence. It is observed that the idioms in the inscriptions such as atı küsi yok bol- "to be forgotten completely",
\end{abstract}

Bu çalışma, 28-29 Ağustos 2020 I. Uluslararası Türkçe edebiyat kültür eğitim sempozyumunda (Bilge Tonyukuk'un anısina) sözlü bildiri olarak sunulmuştur.

Dr. Öğr. Üyesi, Aydın Adnan Menderes Üniversitesi, Eğitim Fakültesi, Türkçe Eğitimi ABD (Aydın, Türkiye), yukselgirgin@hotmail.com, ORCID ID: oooo-0002-0515-6077 [Araştırma makalesi, Makale kayıt tarihi: 12.10.2021kabul tarihi: 20.12.2021; DOI: 10.2900o/rumelide.1036536]

Adres $\mid$ Address

RumeliDE Dil ve Edebiyat Araşturmalar Dergisi $\quad$ RumeliDE Journal of Language and Literature Studies Osmanağa Mahallesi, Mürver Çiçeği Sokak, No:14/8 Osmanağa Mahallesi, Mürver Çiçeği Sokak, No:14/8

Kadıköy - ÍSTANBUL / TÜRKIYE 34714 Kadıköy - ISTANBUL / TURKEY 34714 e-posta: editor@rumelide.com e-mail: editor@rumelide.com, tel: +90 505 7958124, +90 2167730616 phone: +90 505 7958124, +90 2167730616 
ot sub kzl- "antagonize someone in a manner similar to the enmity between the fire and water", uça bar- "fly away, die", adak kamşat- "in the literal sense, to sprain; in the figurative sense to act wrong/misbehave due to feeling baffled" play an active role in strengthening and enriching the expressions in the Turkish vocabulary. The number of words in the inscriptions (in the Kul Tigin, Bilge Qaghan and Tonyukuk inscriptions) is about 6,000, and the number of words used in a different sense is around 840. The study which adopted the qualitative research approach collected the relevant data by using the document analysis technique. When the in-depth background of the proverbs and idioms in the Orhon Inscriptions are assessed in terms of rhetoric, expressiveness, and ability to meet abstract concepts, it is seen that Turkish language gained the identity of a mature language a long time ago. Hence, it can be argued that the Orkon Inscriptions are the most important document in Turkish society's path to becoming a nation in the historical course.

Keywords: Orkon Inscriptions, Turkish vocabulary, idioms, proverbs

\section{Giriş}

M.S. VIII. yüzyılda, gök kadar engin ülkelerin sahibi (Mançurya topraklarından Karadeniz kıyılarına kadar) olanlar, “Göktürler” Orta Asya’nın uçsuz bucaksız bozkırlarındaki yaşanmışlıklarını, öykülerini, dillerini taş sütunlara kazıdılar. Böylece bozkırın ortasına kazınan Türkçe yazılı bu taş köklerden güç alan göçebe Türk boyları, tarihin seyrini değiştiren devletler, büyük medeniyetler kurdular. Bilge Kağan, Kültigin ve Tonyukuk'un anlatımları; taş sütunlar üzerine kazınmış ve kadim Türklerden haber veren ilk yazılı kaynaklardır. Bu nedenle Türk mitolojisinde sonsuz yaşamın sembolü olan "bozkırın bengü taşları", Türklerin tarihte millet olmalarının da başlangıç noktası olma özelliğini taşımaktadır.

Taşlara kazınmış yazılar Türk kültürüne ait en eski yazılı belgelerdir (Kumru, 2017: 17). Bu yazıtlar Türk tarihine ışık tutmakta ve Türklerin devlet, siyaset toplum anlayışını gösteren bulgular içermektedir (Derin, 2014: 465). Türk yurdunun kökeni olmasının yanında birçok dilde "doğu" anlamına gelen Asya; geceleri eksi kırk dereceleri gören dondurucu soğukların, yaşanan kış mevsimi ile birlikte sert karasal iklim özelliklerinin görüldüğü en büyük kıtadır. Kıtanın iç kesimlerine gidildikçe Orta Asya bozkırlarında bu sert karasal iklimin etkileri, kendini daha baskın hâlde hissettirir. Asya'nın bu bölgesinde bu zor iklim koşullarında sadece güçlü olanlar ayakta kalabilmektedir. Fakat böylesine zor bir coğrafyada 1300 yldır hiçbir güce boyun eğmeden dimdik ayakta duran taşlar da bulunmaktadır. $\mathrm{Bu}$ taş sütunlar, kadim Türklerin millet olduğu yerden, 1300 yıl öncesinden bugüne mesajlar taşımaktadır. Bilge Kağan, Kültigin ve Tonyukuk'a ait olan bu mesajlar, anlatılar; ulu bozkırın çocuklarına ezelden ebede kadar kalsın diye sonsuz yaşamın sembolü olan "bengü taşlara” kazınmıştır.

Orhun Yazıtları'nda verilen mesajların bütün zamanları kapsayan paha biçilmez değeri, Türk toplumu için evrensel boyutta yayımlanmış bir manifesto niteliği taşımasıdır (Kuljanova, 2010: 664). Yazıtlar; bir milletin ruhunun derinliklerinden gelen millet olma, devlet olma, insanı yaşat ki devlet yaşasın deneyimi ve tecrübesinin bengü taşa işlenmiş biçimidir. Bu bakımdan, taşa vurulan bir yazı olmasının ötesinde bir milletin kültürel genetiğinin köklü bir deneyiminin ve birikiminin söyleyişidir.

Tonyukuk yazıtı dışında yazıtlarda konuşan kişi Bilge Kağan’ın kendisidir. Bilge Kağan şanlı savaşçı, ordu komutanı, devlet görevlisi kardeşi Kültigin'e olan vefasını göstermek maksadıyla Kültigin yazıtını uçsuz bucaksız Orta Asya bozkırlarının uğrak bir yerine, muhtemelen ipek yolu kervan ticaretinin geçiş güzergâhı üzerine diktirdiğini belirterek milletine birtakım mesajlar vermeyi amaçladığını ifade eder.

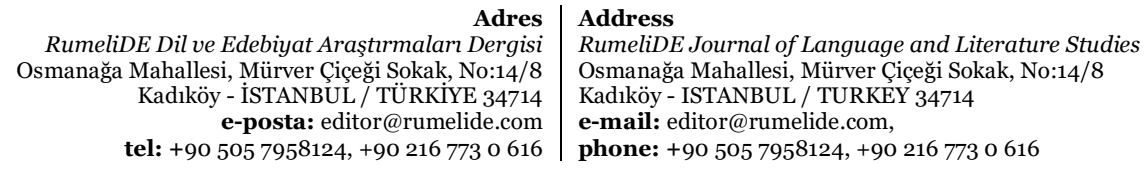


Yazıtın dikiliş amacının geleceğe yönelik olduğunu bu anlamda sözlerinin unutulmaması gerektiğini bildirir.

M.S. 552'de Altay dağlarının eteklerinde Avarların egemenliği altında onlara demir işçiliği yaparak (demirden savaş araç gereçleri yaparak) varlıklarını devam ettiren Türkler, Avarların (Juan Juanların) tahakkümüne, Bumin ve İstemi kardeşlerin önderliğinde başkaldırdılar. Böylece Türk boylarını Göktürk Kağanlığı'nın bayrağı altında topladılar, kişioğullarının yönetimini üstlendiler. Ötüken merkezli Göktürk devletini kurdular. Asya bozkırlarının usta savaşçlları, Göktürk Kağanlı̆̆ı’nın görkemli gücünü göstermek maksadıyla düşmanlarına, baş eğdirip diz çöktürdüler. Bumin ve İstemi kardeşler öldükten sonra devletin idaresinde bulunan kağanların liderlik vasıflarından uzak oluşları, devlet yönetimi alanındaki beceriksizlikleri, Göktürklerin 630 yılında siyasî varlıklarının sona ermesine ve Çin egemenliği altına girmelerine neden oldu.

Türkler, Çin hâkimiyeti sürecinde bağımsızlık anlamında birçok ayaklanma girişiminde bulundular ve sonunda M.S. 682 yılında Kutluk Kağan önderliğinde Çin (T’ang) Hanedanlığı'na başkaldırdılar ve ikinci kez Göktürk Kağanlığı'nı kurdular. Ötüken dağlarında birlik olan Türkler, kendi aralarındaki çekişmelere, kavgalara son verip illerini tuttular, devletlerini kurdular. "İlteriş Kağan" unvanı ile Kutluk, ataları Bumin ve İstemi Kağan'dan sonra ikinci kez göçebe Türk boylarını Göktürk bayrağı altında derleyip topladı ve bir araya getirmeyi başardı.

Türklerin devlet geleneği ve töre anlayışları İslamiyet öncesi dönemde en iyi şekilde Göktürkler zamanında uygulanmıştır. Bu anlamda kağanın tahta oturması ile ilgili yazıtlar, bilgi vermektedir (Koçak, 2011: 106). Yazıtlardaki metinlerin ifade zenginliğinden hareketle Türk dilinin çok daha öncelerden sistematik olarak gelişimini tamamladığını ve metinlerin öğüt vermeye yönelik bir üslup içerdiğini belirtir (Emiroğlu, 2011: 1068-1069).

Dilin sosyolojik varlığı içerisinde önemli bir yere sahip olan deyimler ve atasözleri, bir toplumun dünya görüşünü yansıtmada önemli bir yere sahiptir ve o toplumun düşünce dünyasının dış âleme aksetmesinde önemli rol oynayan dil birlikleridir. Deyimler ve atasözlerinin kültürümüzde önemli bir yeri vardır ve geçmişten günümüze kadar bir milletin ortak duygularını, düşüncelerini hayat tecrübelerini yansitır, onlara zenginlik katar.

Bu çalışma ile Türk dilinin ilk yazılı kaynağı olan Orhun Yazıtlarında Türkçenin söz varlığı olarak atasözleri ve deyimlerin verdiği mesajların dil ve kültür birlikteliği açısından değerlendirilmesi amaçlanmıştır.

\section{Yöntem}

Bu çalışmada, Talat Tekin'in Orhon Yazıtları kitabından ve Türk Dil Kurumunun Atasözleri ve Deyimler Sözlüğü’nden yararlanılmıştır. Çalışma kapsamında nitel araştırma tekniklerinden betimsel doküman incelemesi yöntemi kullanılmıştır. Araştırma yöntemi ile hedeflenen olgular, ilgili bilgiyi içeren yazılı belgelerin çözümlenmesiyle açığa çıkarılıp sistemli bir şekilde değerlendirilmiştir. Bu kapsamda çalışmada betimsel doküman incelemesi yöntemi kullanılarak yazıtlarda geçen 3 atasözü ve sıklıkla tekrar edilen 12 deyim, dil ve kültür birlikteliği açısından değerlendirilmiştir.

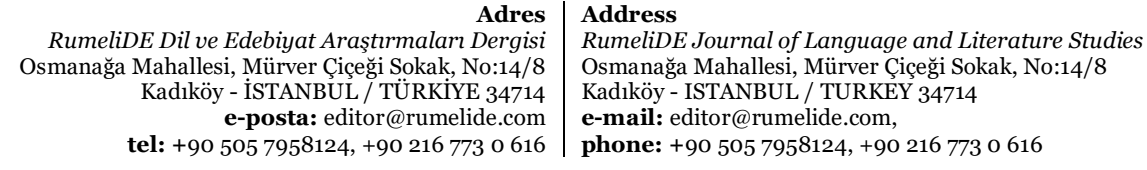




\section{Bulgular ve yorum}

\section{Yazıtlarda geçen atasözleri ve deyimlerin verdiği mesajların, dil ve kültür birlikteliği açısından değerlendirilmesi}

Dil ve kültür birlikteliği, sosyolojik mânâda bir topluma millet olma vasfını kazandıran en önemli yapı taşıdır. Onların duygu ve düşünce dünyalarını kuşatmakla kalmaz, aynı zamanda diğer toplumlar karşısında varlı̆̆ını korumada en önemli rolü oynar. Millî birlikteliğini sağlamış, millet olma iradesini gerçekleştirmiş olan toplumların bulundukları coğrafyada siyasî ve kültürel varlıklarını devam ettirme gayretleri en önemli amaçlarındandır. Bu amaç doğrultusunda kültürel varlıklarını nesilden nesile aktarma gayreti içerisinde olmaları, sosyolojik olgular kapsamında millet olma bilincini korumada öncelik teşkil eder.

Türk toplumunun millet olma yolunda taş sütunlara yazılan kültürel kimliğinin hafızası niteliğindeki metinler, tarihî süreçte iç ve dış etkilerden korunmuştur. Yazıtlarda, Türk milletinin hafızası niteliğinde olan hatırlatıcı anlatımlar, Türk milletinin sosyokültürel genetik yapısını deneyim ve birikimlerini, hayat felsefesini de içermektedir (Demir, 2017: 432). Sosyal psikoloji çerçevesinden bakıldığında dil; bir toplumun kültürel yapısının oluşmasında, yaşamasında gelecek nesillere aktarılmasında en önemli faktördür. Bununla birlikte ortak kültürün oluştuğu, manevî unsurların yoğrulduğu mekânı, yani toprak bütünlüğ̈̈nü de kuşatır. Bu kapsamda dil, toplumu sarıp sarmalar ve kimlik kazanmasında da en önemli etken durumunda olur. Dil, bir toplumun ruh dünyasının dış âleme yansımasıdır.

Resmî devlet yazıtları olmanın ötesinde metinlerde Türk mitolojisine, Türk felsefesine dair bulgular yer almakta ve bu metinler yüksek bir medeniyet algısı içermektedir (Kumru, 2017: 17). Yazıtlarda geçen atasözlerinin o günün şartlarında anlatılan hadiseler çerçevesinde metin içerisindeki kullanım durumuna bağlı olarak farklı anlamlarda kullanıldığı görülmektedir. Bu bakımdan atasözlerinin; tehlike büyümeden önlem almak, tereddüte düşmek, birlik olmak, sabırlı olmak, kendine ve başkalarına zarar vermek, hile yapmak gibi anlamlarda kullanıldıkları tespit edilmiştir.

Orhun Yazıtları'nda geçen atasözlerinin verdiği mesajlar dil ve kültür birlikteliğine etkisi bakımından değerlendirildiğinde;

1. Türük bodun, tokurkak sen: açsık tosık ömez sen; bir todsar açsık ömez sen ${ }^{3}$ : Türk halkı ! Aksisin: acıkırsan doyacağını düşünmezsin, bir doyarsan ackkacağını düşünmezsin.(KT G 8)

Yukarıdaki ifadelerde Türk boylarının, Türk milletinin hayat felsefesi üzerine yapılmış bir çözümlemenin olduğu görülmektedir. Bununla birlikte millet, bu hayat felsefesinin acı sonuçlarına yönelik ciddî şekilde uyarılmıştır. Ayrıca Kağan tarafından dikkate değer bir uyarı da Türk milletinin Türk ülkesinin güneyinde her zaman bir tehdit unsuru olarak yer alan Çinlilere karşı nasıl tutum içerisinde olması gerektiği anlamında yapılmıştır.

Orhun Yazıtları'nda özellikle Bilge Kağan'ın; milletini ve beylerini anayurttan uzaklaşmanın ve Çin entrikalarının rüzgârına kapılıp "millet birliğini" bozmalarının nelere mâl olacağı, uyarı mahiyetinde anlattığı bölümler, hitabet sanatının son derece etkili ve güzel kullanıldığı bölümlerdir (Tekin 1998: 15). Bilge Kağan bu cümleleri ile Türk milletinin sosyolojik anlamda dünyaya bakışını, bir anlamda yaşam

Metinler Türkiye Türkçesine aktarılırken “Tekin, T.(1998).Orhon Yazıtları, İstanbul: Simurg Yayınları” adlı eserden yararlanılmıştır.

Adres Address

RumeliDE Dil ve Edebiyat Araşttrmaları Dergisi $\quad$ RumeliDE Journal of Language and Literature Studies

Osmanağa Mahallesi, Mürver Cicçeği Sokak, No:14/8 Osmanağa Mahallesi, Mürver Çiçeği Sokak, No:14/8

Kadıköy - İSTANBUL / TÜRKIYE 34714 Kadıköy - ISTANBUL / TURKEY 34714

e-posta: editor@rumelide.com $\quad$ e-mail: editor@rumelide.com,

tel: +90 505 7958124, +90 216773 o 616 phone: +90 505 7958124, +90 2167730616 
felsefesini ortaya koymaktadır. Coğrafî koşullar ve iklim şartları Türklerin karakter yapılarının şekillenmesinde önemli rol oynamıştır. Kağan milletini, sosyal psikoloji anlamında iyi tanımaktadır. Bu kapsamda Kağan için devletin devamlılığı bakımından Türk boylarının özgürlükçü karakterini, Asya bozkırlarında at binen ve yay çeken akraba göçebelerin sosyokültürel yapısını bilmek önemlidir.

Orhun Yazıtları, ahenk ve edebî üslûp bakımından Kağan'ın ve milletin karşllıklı görev ve sorumluluklarını içeren taşa yazılmış metinlerdir (Türkmen, 2013: 32). Orta Asya Türk toplumunda kağan bilge bir kişiliktir. Gök Tanrı tarafından kutlanmış bir şahsiyettir. Bu yönü itibariyle "töre" gereği millet de bilge kişilikli kağanın sözünü dinlemekle yükümlüdür. Fakat Türk boylarının karakteristik özellikleri, zaman zaman disiplinsizlikle zaman zaman aksi tutumlarıyla kağanın sözünü dinlemeyip başına buyruk hareket etmelerine neden oluyordu. Bu gibi durumlarda da genellikle Çinlilerin tuzaklarına düşüp felâketle sonuçlanan durumları yaşıyorlardı. Yani devletleri elden çıkıyor, kağansız kalıyor, Çin’in egemenliği altına girip özgürlüklerini kaybediyorlardı. Bu felâket durumları yazıtlarda "kanınız ırmaklar gibi aktı, kemikleriniz dağ gibi yı̆̆ıldı" şeklinde tasvir edilmektedir.

Göktürklerin inanç sisteminde Gök Tanrı her şeye hakîmdir. O, Türk milletini koruyup kollamakla birlikte kağanın sözünden çıktığı zaman da cezalandırırdı. Bununla birlikte verdiği cezayı da affederdi (Yıldırım, 1998: 103). Yazıtların birçok bölümünde millete yönelik hitabet üslubuyla uyarı mahiyetinde bir sesleniş göze çarpar. Liderin sözünün dinlenmesi, bugünün ve yarının hangi şartları beraberinde getireceği, bu kapsamda bir öngörünün olmasından kaynaklanmaktadır. Toplum olarak stratejik düşünme becerisine sahip olunması gerektiği ve kağanın sözünün dinlenerek birlik beraberlik içinde sosyal organizasyonu gerçekleştirerek bu zor coğrafyada milletin varlığının devamını sağlama çabası içerisinde olunması gerektiği tekrarlanarak vurgulanmıştır. Bu kapsamda ifadelerden anlaşılacağı üzere kağanlarının sözünü dinlemeden hareket eden millet de başına gelebilecek felaketlere karşı uyarılmıştır.

\section{Yuyka erikli topulgalı uçuz ermiş, yinçge erkliğ üzgeli uçuz; yuyka, kalın bolsar topulguluk alp ermiş, yinçge yoğun bolsar üzgülük alp ermiş: Yufka olanı delmek kolaymış. Ince olamı koparması kolaymış.Yufka kalın olsa delmesi zormuş. Ince yoğun olsa koparması zormuş.(T G7)}

$\mathrm{Bu}$ atasözünde ifade edilmek istenen durum, Göktürklere karşı ittifak yapmış düşman kuvvetlerin toplanıp bir araya gelmelerine firsat vermeden güçlerini birleştirmeden onlarla ayrı ayrı savaşarak yok etmenin en isabetli karar olacağı anlatılmaktadır (Topsakal, 2018: 307). Bilge Tonyukuk, I. yazıtın güney yüzünde olayların anlatımında kullandığı bu atasözünde düşman kuvvetleri (Çinliler, Kıtaylar Moğollar, Oğuzlar) birleşmeden tehlike büyümeden onların her birine ayrı ayrı saldırarak imha etmek gerektiğini ifade etmektedir. Yazıtlarda casusun getirdiği haber doğrultusunda Tonyukuk, Kağan'ını uyarıyor ve üç düşman kuvveti birleşirse Çinliler, Kıtaylar, Moğollar, Oğuzlar tehlikenin büyüyeceğini kendilerinin düşman karşısında sayıca az olduklarını bu yüzden zor durumda kalacaklarını belirtmektedir. Aynı zamanda iyi bir stratejist olan Bilge Tonyukuk, düşman kuvvetleri birleşmeden ayrı ayrı taarruz ederek yok etmenin en doğru hareket olacağını anlatmaktadır. Yukarıdaki atasözünü de bu duruma istinaden kullanmaktadır.

Kutluk Kağan Göktürkleri bağımsızlı̆̆a kavuşturduktan sonra devletin yeniden teşkilatlanması için bazı yapısal değişikliklere gitmiştir. Ŏguzları mağlup edip Ötüken’i geri almış ve Ötüken merkezli bir yönetim inşa etmiştir. Çin'e karşı verilen bağımsızlık savaşının kazanılmasında kendisine destek olan Tonyukuk'u bu süreçte yanından ayırmamış devlet yönetiminde de danışmanı, "aygucusu" yapmıştır (Çay, 2009: 10). Tonyukuk'un kullanmış olduğu atasözünü, anlam içeriği bakımından günümüz Türkçesinde yer alan "yllanın başını küçükken ezmek gerek" eşdeğer atasözü ile ilişkilendirmek

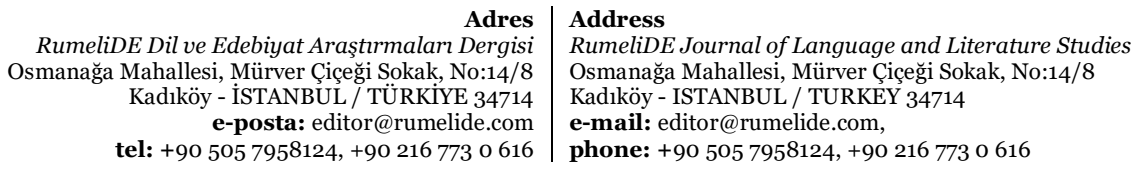


mümkündür. Tehlike büyümeden zamanında önlemini almak gerekli müdahaleyi yapmaktır. Düşman güçlenerek zarar verecek duruma gelmeden tehlikeyi savuşturmak, tehlikeyi bertaraf etmek, düşmana müdahale gerekmektedir.

\begin{abstract}
3) ...“Aygıl!” tidi. Ayığması ben ertim, Bilge Tonyukuk. "Kağan mu kışayın ?” tedim, sakıntım: Toruk bukalı semiz bukalı ırakda bilser, semiz buka, toruk buka teyin bilmez ermiş teyin ança sakıntım. Anta kisre, Tengri biliğ bertük üçün, özüm ök Kağan kışdım:... "Sözcüm ol!” dedi; sözcüsü ben idim, Bilge Tonyukuk. (Bunu) Kağan mı yapayım?" dedim, düşündüm:(insan) zayıf ve semiz boğalar uzaktan böğürse, (insan) hangisinin semiz boğa, hangisinin zayıf boğa olduğunu bilmezmiş ” diye, bu şekilde düşündüm. Ondan sonra, Tanrı akıl verdiği için, (onu) ben kendim Kağan yaptım.(T B 5-6)
\end{abstract}

Çin hâkimiyeti altındaki Göktürk topraklarında doğan Bilge Tonyukuk, soylu bir Türk beyidir. Tonyukuk, Çin kökenli değildir. Çin işgali altındaki Türk topraklarında doğmuştur. Bununla birlikte, Kutluk Kağan'ın Çin'e karşı yapacak olduğu özgürlük isyanını beklemiş ve bu mücadelenin içerisinde yer alacağı güne hazırlanmıştır (Aydın, 2008: 33). Tonyukuk'un “illteriş Kağanı” ilerletmesi ona destek olması, devleti kurma yolunda ona yardımcı olması anlatılmaya çalışılmıştır. II. Göktürk devletinin kuruluş sürecinde Kutluk Kağan 582 yılında Çin Hanedanına 17 kişi ile başkaldırıp isyan sürecini genişleterek 700 kişi olduğunda yanında savaşanların içinde en büyük destekçisi soylu Türk beyi olan Tonyukuk da vardı.

Bilge Tonyukuk'un, asker kimliğinin yanı sıra bürokrat kimliği ve devlet adamlığı profili de mevcuttur. O, Çin'e karşı yapılan isyan girişiminde Kutluk Kağan’ın yanında çoşku ile şevkle yer almış Türk Kağanlı̆̆ını yeniden kurmak için onu kat'i sûretle desteklemiştir (Ata, 2011: 45). Bilge Tonyukuk, yukarıda geçen atasözünü bu duruma istinaden kullanmaktadır. O, Kutluk Kağan’ı destekleyerek Türk milletini Çin esaretinden kurtarıp II. Göktürk Kağanlığı'nın Ötüken'de kurulmasını ve Kutluk Kağan'ın devletin başına geçmesini sağlamıştır.

Yazıtlarda sayı olarak 17 kişi ifade edilen Türk savaş̧̧ı, isyan grubu kendi aralarında oluşturdukları mecliste Kutluk Kağan’ı lider seçerler. Çok kısa bir sürede yayılan isyân sonrası bu sayı önce 70 sonra 700 olur. İsyânın genişleyip başarıya ulaşması ile 682 yılında II. Göktürk Kağanlığı, Kutluk önderliğinde Ötüken merkezli devlet yapılanması ile siyasi ve askerî kimliğine yeniden kavuşur (Demirbilek, 2016: 49).

Bu eski Türk atasözünde anlatılmak istenen, Tonyukuk'un İlteriş Kağan’a yardımcı olup kağanlığı kurmasına yardım etmek veya etmemek anlamında bir tereddüt geçirme durumu düşüncesidir. Ardından boğanın semizi, zayıfı uzaktan ayırt edilmez deyip İlteriş Kağan’ın liderliğine kanaat getirmesi ve sonrasında kağan olmasında ona yardım etme düşüncesine istinaden söylenmiş bir atasözüdür.

İlteriş (Kutluk) Çin tahakkümüne karşı isyan girişiminde bulunup 700 kişilik orduyu komuta ettiğinde İlteriş, Tonyukuk'a kendisine katılması için teklif gönderir. Bu sırada Tonyukuk İlteriş’i, Kağan olarak tanımakta bir tereddüt geçirir. Tonyukuk atasözünü bu durumu anlatmak için kullanır. Atasözünün "tereddüte düşmek, tereddüt etmek" anlamına geldiği ifade edilmektedir (Elçin, 2004: 633).

Orhun Yazıtları'nda metinlerin içinde o günkü Türkçenin ifade gücü göz önünde bulundurulduğunda soyut ve somut kavramları karşılayan çok fazla deyimle karşılaşılmaktadır. Bu anlamda yazıtlarda geçen anlatımı zenginleştiren, güzelleştiren, güçlendiren deyimleri dil ve kültür etkileşimi bakımından şu şekilde değerlendirmek mümkündür.

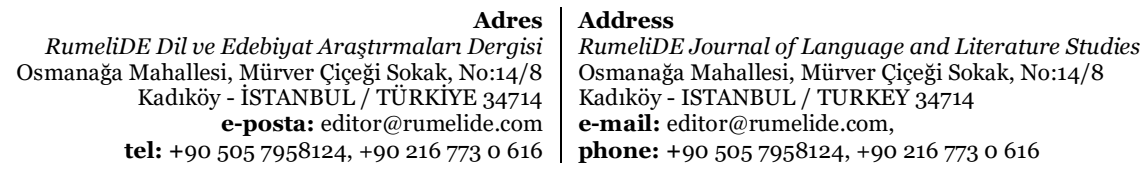


1) atı küsi yok bol- "adı sanı yok olmak"

Türük bodunug atı küsi yok bolmazun tiyin, kangım Kaganı̆̆ öğüm Katunuğ kötürüğme Tengri, il biriğ[me T]engri, Türük bodun atı küsi yok bo[lmazun tiyin, özümin ol Tengri] Kagan olurtdı erinç. Tengri yarlıkadukın üçün özüm kutum bar üçün Kagan olurtum: Türk milletinin adı samı yok olmasın diye, babam Kağanı ve annem Katunu yüceltmiş olan Tanr, devlet veren Tanrı, Türk milletinin adı sanı yok olmasın diye beni o Tanrı tahta oturttu. Tanrı lütfettiği için, ben de kutlu olduğum için tahta geçtim.(K D25)

Göktürk kağanları, Türk milletine kendi evlatlarından, taya benzer oğullarından iyi bakıyordu, besliyordu, gözetiyordu fakat o kağanlar uçmağa erdi (Tanyeri, 2011: 103). Yazıtlarda kağanların liderlik vasıfları kapsamında millete duyulan derin bağlılığın var olduğu görülmektedir. Bu kapsamda, kağanların milletine karşı duyarlı oldukları milleti bir arada tutma, varlığını koruma, onların karnını doyurma gibi durumların sosyal devlet anlayışı kapsamında kağanların asli görev alanları içerisinde olduğu bilinmektedir.

Gök Tanrı'dan kutlu olan kağan; milletin karnını doyurmak, birliğini dirliğini temin etmek, güvenliğini sağlamakla sorumluydu ve bütün bunlar, millete karşı asli görevleri arasında yer alıyordu (Taşağıl, 2014: 179). Bu duruma karşıllk da millettin (Türk boyları, Türk beyleri) Gök Tanrı'dan kutlu olan bilge kişilikli kağanlarının sözünü tutmak onun sözünden dışarı çıkmamak, milletin birinci derece sorumluluğu arasinda yer alıyordu.

İslamiyet öncesi Orta Asya Türk boylarında Tengricilik inancı vardı. Bu din anlayışında kağan olacak kişiye Gök Tanrı tarafından "kut” verilirdi. Böylece kağan olacak kişi Tanrı tarafından onanmış olurdu. “Kut” Orta Asya Türk boylarının inanç dünyasında Gök Tanrı'nın verdiği yaşam gücü, kutsal enerjiydi. Kağanların tahta oturması, düşmanlarını mağlup edip savaş kazanmaları, yeryüzünde Gök Tanrı'nın gölgesini temsil etmeleri bütünüyle bu kutsal enerjiye bağlıdı. Orta Asya Türk boylarının inanç dünyasında herhangi bir nedenle Gök Tanrı, kağana verdiği "kut’u”, "kutsal enerjiyi” geri alırsa o zaman savaş meydanlarında zafer kazanamazlar, tahtlarını kaybederler, milletinin gözünden düşerler, liderlik vasıflarını kaybederler, yeryüzünde Gök Tanrı’nın gölgesi olma durumundan çıarlardı.

2) kızıl kanın töküt-, kara terin yüğürt- "kızıl kanını akıtmak kara terini dökmek, çok emek vermek, çok çalışmak"

Tün udımatı, küntüz olurmatı, kızıl kanım töküti, kara terim yüğürti işiğ küçü̆ğ bertim ök : Geceleri uyumadan, gündüz oturmadan kızll kanımı akıtarak kara terimi dökerek hizmet ettim.(T; D-2 ikinci taş)

Tonyukuk, yaşadığı dönemde yaptığı hamlelerle Kutluk Kağan’ın ve Kapgan Kağan'ın danışmanı, ordu komutanı sıfatı ile Türk boylarını Göktürk Kağanlığı'nın bayrağı altında topladı; Uygurlar, Kırgızlar, Oğuzlar, Türgişler olmak üzere bütün Türk boylarını birleştirdi. Bu coğrafyada, ulu bozkırda birlik olmak, güçlü olmak demekti.

Kutluk ile Bilge Tonyukuk Çin egemenliği altında bulunan Türk boylarını ayaklandırıp Türklerin özgürlükçü karakterini Ötüken'de Göktürk bayrağı altında toplamıştır (Taşağıl, 2012: 470). Bilge Tonyukuk, Türk boyları arasında birlik ve düzeni sağlamada Göktürk Kağanlı̆̆ı'nın kurulmasında Kutluk Kağan, Bilge Kağan, Kültigin kadar liderdi. Bundan dolayı ilk yazıtlar, ilk yazılı metinler ve geleceğe gönderilen ilk mesajlar ona aittir. Türk boylarının sosyal bütünleşmesini gerçekleştirmesi anlamında "kızıl kanını dökmüss, kara terini akıtmış, gece uyuyası gelmemiş gündüz oturası gelmemiş" bilge bir kişiliktir. Bununla birlikte Türk boylarının bozkırda bütünleşmesini tamamladığı, organize olduğu kültürel yapı töredir, sosyal yapı devlettir. O dönemde kurulan bu birlik, bugün de Türk Dünyası'nın yakınlaşmasının en kadim ve sağlam temelini oluşturmaktadır.

Adres Address

RumeliDE Dil ve Edebiyat Araştırmaları Dergisi $\quad$ RumeliDE Journal of Language and Literature Studies Osmanağa Mahallesi, Mürver Çiçeği Sokak, No:14/8 Osmanağa Mahallesi, Mürver Çiçeği Sokak, No:14/8 Kadıköy - ÍSTANBUL / TÜRKIYE 34714 Kadıköy - ISTANBUL / TURKEY 34714 e-posta: editor@rumelide.com e-mail: editor@rumelide.com, tel: +90 505 7958124, +90 2167730616 phone: +90 505 7958124, +90 2167730616 
Tonyukuk, 681-682 yıllarında Kutluğ’un, Türklerin özgürlükçü karakterini harekete geçirip bağımsızlık isyanını başlatmasıyla Çin tahakkümüne karşı yapılan bu mücadelenin içerisinde yer almış milletinin istiklâli için Kutluğ’un yanında savaşmıştır (Bardakçı, 2018: 308).

Yukarıdaki deyimsel ifadeler Bilge Tonyukuk yazıtında geçmektedir ve Türk Kağanlı̆̆ı'nın yeni döneminde; gece uyumadan, gündüz oturmadan kızıl kanını, kara terini akıtarak yaptığı çalışmalarını, neler yaşadığını, önce o günkü halkına ve sonra yüzyıllar ötesine bu taş sütunlarda anlatmıştır. Tonyukuk, büyük devlet adamı vasfı taşımakla birlikte aynı zamanda bilge bir kişiliktir ve ordu komutanıdır. Verdiği kararlarla yalnız yaşadığı zaman dilimini değil, yüzyıllar ötesini etkileyen öngörüye sahip stratejist, aynı zamanda dilinin ilk edebî metnini yazan, kendi hatıralarını anlatan ediptir. Devletinin tarihini taşlara nakşeden ve yazdıklarını yüzyıllar ötesine ulaştıran bir tarih yazıcısıdır.

3) başlı̆̆ı̆̆ yeküntür-, tizliğĭg sökür-"başlıya (mağrura) baş eğdirmek, dizliye (güçlüye) diz çöktürmek"

Kamağı] biş otuz sü[ledim]iz, [üç̧ yiğir]mi [süngüşdimiz. İlliğiğ ilsiretdimiz, kağanlı̆̆ğ kağansıratdımız. Tizliğiğ] sökürtümiz, başh̆ğğ yüküntürtimiz: Toplam yirmi beş kere sefer ettik; on üç kez savaştık. Devletliyi devletsiz; kağanlıyı kağansız bıraktık. Dizlilere diz çöktürdük, başhlara baş eğdirdik.(BK D15-16)

Göktürklerin yaşadıkları coğrafyada hâkim güç olması, yazıtlarda yukarıda ifade edilen deyim vasıtasıyla sık sık tekrarlanır. Bu anlamda özellikle Bilge Kağan, Kültigin abidesinde "dizliye diz çöktürdük, başlıya baş eğdirdik" deyimi metinlerde Türklerin kurduğu devletin ihtişamını ve gücünü tasvir etmede sıkça kullanılmaktadır.

İleride gün doğusuna, güneyde gün ortasına kadar, geride gün batısına ve kuzeyde gece ortasına bu sınırlar içindeki bütün halklar hep bana tâbidir. Dört bucaktaki halkları hep kendime bağımlı kıldım (Tekin, 1998: 35). İklim koşulları itibariyle zor bir coğrafyada var olma mücadelesi veren göçebe Türk boylarının karakteristik özelikleri güçlü, savaşçı bir toplum olmalarıydı. Bu yönü itibariyle sosyal bütünleşmelerini sağladıklarında ve kendi içlerinden bir lider çıkartıp liderin önderliğinde sosyal bütünleşmenin vücut bulduğu devlet organizasyonunu gerçekleştirdiklerinde (İllerini tuttuklarında, törelerini düzenlediklerinde) düşmanlarına karşı da üstünlük kurabilmekte ve görkemli güçlerini ortaya koyabilmekteydiler.

4) içre aşsız taşra tonsuz- "içi aşsız, dışı giysisiz" (karnı aç, sırtı çıplak)

[Neng y]ılsı̆ bodunta üze olurmadım. İçre aşsız taşra tonsuz yabız yablak bodunta [üze olurtum] : Zengin milletin üzerine Kağan olmadım. Tam tersine karnı aç, sırtı çılak, kötü ve perişan durumdaki milletin üzerine Kağan oldum.(BK D21-22)

Bilge Kağan dağınık hâldeki Türk boylarını bir araya toplamış, milletini doyurmuş ve bu coğrafyada var olması için yeniden diriltmiştir (Enginün, 2010: 345). "Töre" Türk toplumunda gelenek ve göreneğe bağlı yazılı olmayan kanun, yaptırımı olan kurallardır. Bu kapsamda ve Gök Tanrı'nın "kutlu” tercihi doğrultusunda kağanların kendilerini millete adamışlı̆̆ söz konusudur. Kendini milletine adamak kadim Türk kültüründe sosyolojik anlamda "alp insan" tipi ile de karşımıza çlkmaktadır. "Alp kişi” milleti için savaşan milletinin varlı̆̆ına hizmet eden insandır. Bu kapsamda milletin her daim var olması, milletin birliği, dirliği açlığı tokluğu kısacası sosyoekonomik durumu ve güvenliği kağanın sorumluluk alanı içerisindedir. Bu sorumluluk doğrultusunda çalışma azmini ifade eden cümleler yazıtlarda sıklıkla görülmektedir. Diğer yönden millette kağanın hükümranlığını tanımak, ona biat etmek, sözünü tutmakla, liderine bağlılıkla yükümlüydü. Millete adanmışlık anlayışı kapsamında Bilge

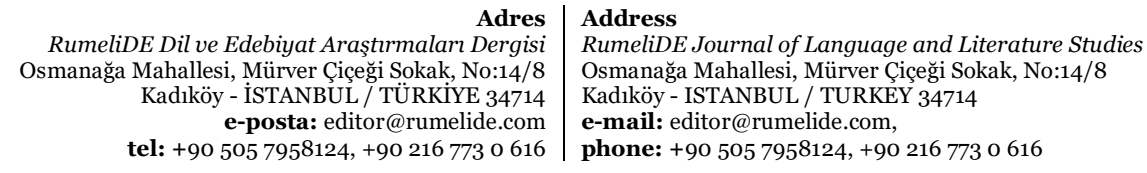


Kağan, yoksul, bitap düşmüş Türk boylarına Kağan olduğunu, gecesini gündüzüne katarak iki Şâd ve Kültigin ile ölmek üzere olan bir milleti dirilttiklerini, yok olmaktan kurtardıklarını ifade eder.

Türkler ekonomik faaliyet olarak Asya bozkırlarında geçimlerini avcllık ve hayvancılık yaparak sağlıyorlardı. İklim koşulları tarımsal faaliyet ve tahıl üretimi yapmalarına yeterince imkân tanımıyordu. Bundan dolayı tarımsal üretime geçemeyen toplumların tahıl üreten yerleşik toplumlar ile uzun süre mücadele etmeleri zordu. Türkler nüfus yoğunluğu olarak Çin toplumundan azdı fakat nitelikli savaşçılardı. Çinliler sayıca fazla olmalarına rağmen Budizm’den dolayı karakteristik özellikleri Türkler gibi dinamik toplum özelliğine sahip değillerdi. Diğer taraftan Türk ülkesinde sıklıkla kitlık durumu baş gösterirdi. Bazen birkaç yılı aşkın yağışın olmadığı durumlar olurdu. Bazen de yaz aylarında bile kar yağışının görüldüğü zamanlar yaşanırdı. Böylesi kıtlık durumlarında kağan milletini tahıl üretiminin yapıldığı Çin sınırlarına doğru götürür ve savaştırırdı. Bu gibi durumlarda Çinliler Türkleri tuzağa düşürürlerdi. Fakat Türkler geri çekilip derlenip toparlandıkları zamanda karşı saldırıya geçerek üstünlük sağlarlardı.

5) biriki budunuğ ot sub kal- "birleşik milleti ateş ile su gibi birbirine düşman etmemek"

İnim Kül T[igin birle, eki şad] birle ölü yitü kazgantım. Ança kazganıp birki bodunuğ ot sub knlmadım : Kadeşim Kül Tigin ve iki şad ile birlikte öle yite çalışıp kazandım. Böyle kazandığım için birleşik milleti ateş ile su gibi birbirine düş̧man etmedim.(BK D21-22)

Yazıtlarda farklı isimler taşıyan Türk boylarının millı̂ birliğinin sağlanması sıklıkla vurgulanmış bu hususta kağanlar çok çalışmıştır (Orhan ve diğerleri, 2012: 911). Orta Asya bozkırlarında göçebe Türklerin iki büyük düşmanı vardı. Birincisi Çin (Tabgaç, T’ang Hanedanlığı), ikincisi Türk boylarının kendi aralarındaki rekabet ve iç çekişmeleriydi. Yani kardeş kavgalarıydı ve zaman zaman da kağanına karşı olan söz dinlemezlikleriydi.

Türk boylarının sahip olduğu bağımsızlık arzusu, coğrafya kaynaklı özgürlükçü bir karaktere sahip oluşları, Türk boylarının birbirleri ile mücadele alanları Çin’in bölgesel siyasetinde dikkate değer unsurlar olarak hep göz önünde bulundurulmuştur (Mert, Bozkırlı; 2015: 4). Çin Hanedanlı̆̆ı ipek yolu ticaret güzergâhının Türk boylarının kontrolünde olması nedeniyle sıklıkla Türk boylarını birbirine düşürmek için kışkırtıcı faaliyetlerde bulunmakta kendisi ile işbirliği yapan Türk boyunun beyine bozkurt figürlü bayrak göndererek o boyu devlet statüsünde tanıdığını ima etmekteydi. Böylece Çin Hanedanlığı, Türk boylarının Çin’e karşı olan birlik ve bütünlüğünü bozup kendi aralarında karışıklık çıkartarak Çin hâkimiyeti altına alma gayreti içerisine girerdi. Bu anlamda, Bilge Kağan Çin politikasını, "Tatlı sözlerle ve yumuşak ipeklilerle kandırıp uzak halkları yakınlaştırır ve içinde eritir" cümlesiyle anlatmaya çalışmıştır.

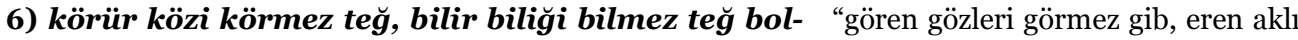
ermez gibi olmak" (iş göremez, düşünemez duruma gelmek)

İnim Kül Tigin kergek bolth özüm sakıntım. Körür közüm körmez teg bilir biliğim bilmez teğ bolth. Özüm sakıntım. Öd tengri aysar kişi oğlı kop ölgeli törimiş: Kardeşim Kül Tigin vefat etti. Kendim yas tuttum. Gören gözlerim görmez gibi, eren aklım ermez gibi oldu. Kendim düşünceye daldım. Zaman tanrısı buyurunca (zamanı Tanrı tayin eder) insanoğlu hep ölümlü (ölmek için) yaratılmış.(KT D-11)

Bilge Kağan, Kültigin’in ölümünden büyük üzüntü duyar. Kültigin, Bilge Kağan’ın kardeşi olmasının yanında en önemli yardımcısıdır. Amcası Kapgan Kağan'ın ölümünden sonra babalarının kurduğu devletin yönetimini, 716 yllında amcaoğullarını tasfiye ederek ele geçirirler. Bu olayda Kültigin önemli

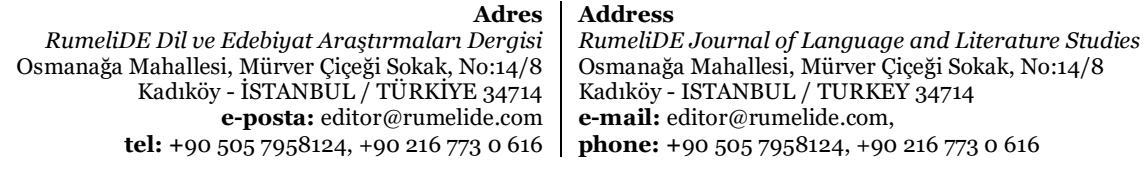


rol oynadı ve ağabeyi Bilge Kağan'ın Kağan olarak tahta geçmesinde devletin yeniden görkemli gücüne ulaşmasında çok büyük katkısı oldu.

Bilge Kağan, kardeşi Kültigin’in kahramanlığını yazıtlarda sıklıkla yâd eder ve ona "İnançu Apa Yargan Tarkan” unvanını verdiğini söyler. İkisi birlikte hareket ederek kayınbabası Tonyukuk ile güçlerini birleştirip Türk ilini düzene koyarak Çin tehdidine karşı mücadele etmişler, Türk milletinin bozkırın ortasında yok olup gitmesinin önüne geçmişlerdir. Bilge Kağan, çok değerli kardeşi “ulu bozkırın keskin kılıı” Kültigin’i kaybetmenin derin üzüntüsünü yukarıdaki deyimde geçen ifadeler ile tasvir etmektedir.

7) közi kaşı yablak bol- "gözü kaşı mahvolmak” (aşırı yastan perişan duruma gelmek, saçı başı yolunmak)

Közde yaş kelser tıda, köngülte sı̆̆ıt kelser yanturu sakıntım. Katığdı sakıntım. Eki Şad ulayu iniygünüm, oğlanım, beğlerim bodunum közi kaşı yablak boltaçı tip sakıntım: Gözümden yas gelse engel olarak, gönülden feryat gelse geri çevirerek yas tuttum. Çok yas tuttum. Íki Şad başta olmak üzere kardeşlerimin, oğullarımın, beylerimin (ve) halkımın gözleri kaşlar berbat olacak diye kayglandım.(KT K-11)

Yazttlarda geçen bu deyimde yine Bilge Kağan kardeşi Kültigin’in ölümü üzerine duyduğu üzüntüyü dile getirir. Bilge Kağan'ın kardeşine olan vefasını göstermek için Kültigin'in ölümünden sonra Kağan statüsünde bir cenaze töreni düzenler. Bu yüzden onun anısına, ona duyduğu minnet ve şükran duygusuna istinaden Kültigin anıtını inşa ettirmiştir. Kültigin Göktürklerin gök kılııı; Çin kaynaklarında "Onun kılıcına teslim olmayan kimse olmamıştır”, " yenilmez savaşçı ” gibi ifadelerle anılmaktadır. O, Türk tarihinin ve göçebe Türk boylarının hükümdar şahsiyetlerindendir.

II. Göktürk Kağanlığı'nın güçlenmesinde gök kadar engin ülkelerin fetih edilmesinde (Mançurya topraklarından Karadeniz kıyılarına kadar) Kültigin önemli rol oynamıştır. Devlet yönetiminde ağabeyi Bilge, Kağan olmakla birlikte ordunun yönetimi Kültigin’in elindedir ve Göktürk ordularının başkomutanıdır. Türk göçebe boylarını Göktürk Kağanlığı bayrağı altında toplayan Asya coğrafyasının engin ülkelerini hâkimiyeti altına alan Kültigin, şüphesiz ki Türk ilinin ulu bozkırın büyük komutanıydı. $\mathrm{O}$ göçebeliler tarihinde tanınan en iyi yönetici ve aynı zamanda Türk boylarının yılmaz savaşçısıdır. Bu anlamda büyük göçebeliler coğrafyasında Göktürklerin hâkim güç olmasında en önemli rolü oynamıştır denilebilir. Bundan dolayı ağabeyi Bilge, Kültigin’e olan vefasından dolayı Kağan unvanı taşımamasına rağmen kağanlara yakışır bir cenaze töreni düzenlemiştir. Kardeşi Kültigin'in ölümü Bilge Kağan’ı çok sarsmıştır. Yukarıdaki cümlede geçen deyimde de bu derin üzüntü anlatılmaya çalışılmıştır.

8) adak kamşat- “ayağı burkulmak, ayağı dolaşmak, sendelemek (morali bozulmak, şaşırıp yanlış hareket etmek) mecazen "maneviyatı bozulmak"

[..........̈Ü]çünç [Çuş başınta sü]ngüşdüm. Türük bodun adak kamşattt, yablak boltaçı erti. Oza yanya keliğme süsin ağıttım: Üçüncü olarak Çuş ırmağı başında savaştım. Türk halkının ayă̆ı sendeledi, fena olacak idi. (Saflarımızı) yarı dağıtarak gelen ordusunu geri püskürttüm.(BKD-3o)

Bu deyim anlam itibariyle yazıtlarda, morali bozulmak, maneviyatı bozulmak anlamında kullanılmıştır. Türklerin bu coğrafyada sert iklim koşullarının dışında iki düşmanı vardı. Birincisi Çin emperyalizmiydi. İkincisi ise kendi aralarındaki çekişmeler, iktidar mücadeleleriydi.

Türklerin toplum düzeninin temelini farklı isimlerdeki "boylar" şekillendirirdi. Bu "boylar", "bey" unvanı taşıyan liderleriyle kendi egemen yapılarını muhafaza ederek bir araya gelirler ve konfederatif, üst birlik olan sosyal yapılar meydana getirirlerdi. Ancak bozkırda Türklerin sosyal hayat tarzları oldukça hareketli ve değişkendi. Türkler, yabancı toplum unsurlarıyla savaştıkları gibi sıklıkla kendi

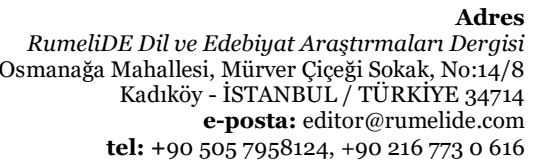

Adres
RumeliDE Dil ve Edebiyat Araştırmaları Dergisi tel: +90 505 7958124, +90 2167730616
Address

RumeliDE Journal of Language and Literature Studies

Osmanağa Mahallesi, Mürver Çiçeği Sokak, No:14/8

Kadıköy - ISTANBUL / TURKEY 34714

e-mail: editor@rumelide.com,

phone: +90 $5057958124,+902167730616$ 
aralarında da savaşırlardı. Bunun için üst birlik sosyal yapı kısa sürede dağılabiliyordu (Kaplan, 1985: 2). Bilge Kağan yazıtının doğu yüzünün 30. satırında anlatılmaya başlanan olaylarda Bilge Kağan benim halkım dediği Dokuz Oğuzlar ile dört kez savaştı̆̆ını anlatmaktadır. Ancak üçüncü savaşta, Çuş ırmağı başında yapılan savaşta, Türk halkının moralinin bozulduğunu, ayağının sendelediğini belirtmekle birlikte onları toparladığını Dokuz Oğuzları geri püskürttüğünü anlatmaktadır.

9) ilin törüsin tuta birmiş- "il tutmak, töre düzenlemek, Türk halkının devletini ve yasalarını yönetivermiş ve düzenleyivermişler"

Üze kök tengri asra yağız yer kılıntukda, ekin ara kişi oğlı kılınmış. Kişi oğlınta üze eçüm apam Bumın Kağan, İştemi Kağan olurmış. Olurpan, Türük bodunıng ilin tör[üs]in tuta birmiş, iti birmiş : Üstte mavi gök(yüzü) altta (da) yağız yer yaratıldığında, ikisinin arasında insan oğulları yaratılmış. Insan oğullarını üzerine (de) atalarım dedelerim Bumin Hakan, İștemi Hakan (hükümdar olarak) tahta oturmuş. Tahta oturarak, Türk halkının devletini (ve) yasalarm yönetivermiş (ve) düzenleyivermişler.( $K T D-1 ; B K D-3)$

"Töre", Türk toplumunda devletin varlığı ve boyların birliğini sağlayan sosyal hayatı düzenleyen genel nizami kurallar bütünüdür (Mert, Bozkırlı; 2015: 12). Millet olma duygusu ve bilinci, Göktürkler döneminde en yüksek seviyede yaşanmıştır. Yazıtlarda, "İl tutup töre düzenlemek" ifadesi ile "il" devlete işaret ederken, "töre" eski Türklerde yönetim sistemi ve devletin mânâ zeminini oluşturmaktadır. Bozkırda, Kağan’ın sözüne bağlı olan ve töreye tabi olan farklı isimlerdeki akraba boyların “Türk” ismiyle üst birlik, üst kimlik ile budun, millet olarak bir araya getirilmişlerdir.

Çin Seddi’nin kuzeyinde varlığını devam ettiren, at binen "yay çeken” bütün göçebe akraba boylarını birleştirme çabası, Mete (MÖ 209-179) Büyük Hun İmparatorluğu hükümdarından beri mevcuttur. Bu amaç doğrultusunda göçebe akraba boyları, sosyolojik mânâda millet hâline getirip siyasi birlik sağlama, düşman halklara karşı da güç oluşturma gayreti hedeflenmiş olacaktı (Mert, 2009: 3). Orhun Yazıtları'nda sosyal hayatta ve diğer alanlarda hukuk düzeninin töre ile sağlanması, kağanların il tutup devleti kurduktan sonra töreye nizam vermeleri, devletin varlığını ve milletin birliğini sağlayan yazılı olmayan "töre" faaliyetleri, kağanın seçilmesinde de belirleyici olması, Bilge Kağan’ın yukarıdaki ifadelerinde geçen deyim vasıtası ile anlatılmaktadır.

10) il tutsıkıngm-"devlet sahibi olmak"

Türük beğler, bodun, bunı eşiding! Türük [bodun ti]rip il tutsıkngmn bunta urtum; yangılıp ölsiking in yeme bunta urtum. Neng neng sabım erser benggü taşka urtum : (Ey) Türk beyleri (ve) halkı, bunu işitin! Türk (halkı), dirilip (nasil) devlet sahibi olacağım buraya (taş üzerine) hakkettim; yanılı (nasıl) öleceğini de buraya hakkettim.(Söyliyecek) her ne sözüm var ise ebedî taşa hâkkettim.( KT G-10)

Türklerde devlet anlayışı ilahî kökenlidir. Gök Tanrı; tanrısal gücü, "kut" verdiği kişiyi Kağan olarak tayin eder, kişioğlunun üzerine kılar.

Türklerin inanç sisteminde kağanlık, kişiye gökte bulunan tanrısal gücün izni ile verilirdi ve kağan her zaman bu durumun bilinci içerisinde olurdu. Bu kapsamda kağanın kazandığı savaşlar veya kaybettiği savaşlar bütünüyle gökte bulunan tanrısal gücün iradesi kapsamında gerçekleşmektedir. Kutluk Kağan'ın bağımsızlık isyanını başlattığında yanında yer alan on yedi arkadaşının içinden kağan seçilmesi, Gök Tanrı tarafından "kut" verilmesi ile olmuştur. Kutluk bu sayede "kut'a" kavuşmuş milletini yeniden gök bayrak altında toplamayı başarmıştır (Demirbilek, 2016: 50). Gökteki tanrısal güç Türk milletinin varlığı devam etsin diye kağan gönderir bu kağanlar, düşman orduları karşısında onun sayesinde muzaffer olur, savaşı kazanırdı (Derin, 2014: 470).

\footnotetext{
Adres $\mid$ Address

RumeliDE Dil ve Edebiyat Araştırmaları Dergisi $\quad$ RumeliDE Journal of Language and Literature Studies Osmanağa Mahallesi, Mürver Çiçeği Sokak, No:14/8 Osmanağa Mahallesi, Mürver Çiçeği Sokak, No:14/8 Kadıköy - ISTANBUL / TÜRKIYE 34714 Kadıköy - ISTANBUL / TURKEY 34714 e-posta: editor@rumelide.com e-mail: editor@rumelide.com, tel: +90 505 7958124, +90 2167730616 phone: +90 505 7958124, +90 2167730616
} 
Yukarıdaki ifadelerde ve bu deyimin anlam derinliğinde Türk milletinin, Türk beylerinin kağanın "bilge sözünü” dinleyerek toplumun birlik ve dirliğinin korunabileceği, il tutup devlet sahibi olunabileceği, bunların dışına çıkıldığında ise Türk milletinin yanılıp öleceği, gelecek nesillere de rehber olsun diye bu taşa vurulduğu, kazındığı anlatılmaya çalışılmıştır.

11) tün udıma-, küntüz olurma- "geceleri uyumamak, gündüzleri oturmamak" ( gece gündüz demeden çalışmak, çok çalışmak)

T]igin iki şad inim Kü[[l Tigin [bir]le sözleşdimiz: Kangımız eçimiz kazganmış bodun atı küsi yok bo[lmazun] tiyin Türük bodun üçün tün udomadrm, küntüz olurmadom; İnim Kül T[igin birle iki şad] birle ölü yitü kazgantım: Prens iki şad (ve) kardeşim Kül Tigin ile konuşup anlaştık. Babamızın (ve)amcamızın kazanmış oldukları milletin adı sanı yok olmasın diye, Türk halkı için gece uyumadım; gündüz oturmadım; kardeşim Kül Tigin ve iki şad ile (birlikte) öle yite çalışıp kazandım.(BK D-22 ; KT D-27)

Milletin ve devletin var olması için Bilge ve Kültigin kardeşlerin ortak çaba ve işbirliği içerisinde olmaları, statü farkı oluşturmadan yardımlaşmaları sosyokültürel mânâda "dayanışma" değeri ile örtüşmektedir (Enginün, 2010: 345). Türk Kağanlığı'nın yeni döneminde (II. Göktürk Devleti) Bilge Kağan, gece uyumadan, gündüz oturmadan milleti için yaptığı çalışmalarını, neler yaşadığını o günkü halkına duyurmak ve yüzyıllar ötesine ulaştırmak için diktirmiş olduğu taş sütunlarda anlatmıştır.

Bilge Kağan, büyük devlet adamı vasfı taşımakla birlikte aynı zamanda lider bir kişiliktir. Bununla birlikte devletinin tarihini taşlara nakşeden bir edip ve hitabet ustasıdır. Onun mesajları günümüzde de geçerliliğini güçlü bir şekilde korumaktadır. Bu deyimin anlam içeriğinde de milleti ve devleti için özveriyle çalışan gecesini gündüzüne katan devlet adamı akla gelir. Yazıtlarda, Göktürk Kağanları’nın milletin refahı için gece gündüz demeden çalıştıklarını anlatan ifadelerin sıklıkla geçtiği dikkat çeker.

12) ölü yitü kazgan- " öle yite, ölesiye çalışıp kazanmak"

Kangımız eçimiz kazganmış bodun atı küsi yok bo[lmazun] tiyin Türük bodun üçün tün udımadım, küntüz olurmadım; İnim Kül T[igin birle iki şad] birle ölü yitü kazgantım : Babamızın (ve)amcamızın kazanmış oldukları milletin adı sanı yok olmasın diye, Türk halkı için gece uyumadım; gündüz oturmadım; kardeşim Kül Tigin ve iki şad ile (birlikte) öle yite çalsşıp kazandim.(BK D-22; KT D-27)

Yazıtlarda Kağan'ın milletine karşı duyduğu derin bağllı̆̆ı ve koruma güdüsünü ifade eden cümleleri Bilge Kağan'ın ve Tonyukuk'un ağzından duymak mümkündür. Bu deyimde de Türk milletinin var olması için gece uyumadan gündüz oturmadan ölesiye çalışmak biraz önce ifade ettiğimiz Kağan'ın milletine olan duyarlılığı kapsamında değerlendirmek gerekir.

Göktürk Kağanları'nın hâli perişan olan milleti zengin kılmaları, doyurup varlıklı hâle getirmeleri, bolluk içinde yaşatmaları, nüfusu artırıp düzene sokmaları, onları örgütleyip töre kapsamında devlet sahibi yapmaları, birlik ve dirliklerinin sağlanması, onları refah seviyesi yüksek toplumlardan daha ileri seviyeye getirmelerinin yazıtlarda anlatılması, kağanların ayırt edici özellik anlamında hizmetkâr bir lider profili ortaya koyduğunu göstermektedir (Tanyeri, 2011: 104-105).

\section{Tartışma ve sonuç}

Yazıtlarda atasözleri ve deyimlerin dil ve kültür birlikteliği açısından verdiği mesajlar değerlendirildiğinde, VIII. yüzyılda taşlara kazınmış bu metinlerdeki mesajlar günümüzde de aynı anlam zenginliğini koruduğu gözlenmektedir. Bundan dolayı atasözü ve deyimlerin Türkçenin söz varlığı içerisindeki önemi, anlam derinliği, dilin imkânları içerisinde geçerliliğini korumaktadır. Yazıtlarda geçen atasözlerin ve deyimlerin dil ve kültür birlikteliği açısından verdiği mesajlar dikkate

Adres | Address

RumeliDE Dil ve Edebiyat Araşturmalar Dergisi $\quad$ RumeliDE Journal of Language and Literature Studies Osmanağa Mahallesi, Mürver Çiçeği Sokak, No:14/8 Osmanağa Mahallesi, Mürver Çiçeği Sokak, No:14/8 Kadıköy - ÍSTANBUL / TÜRKIYE 34714 Kadıköy - ISTANBUL / TURKEY 34714 e-posta: editor@rumelide.com e-mail: editor@rumelide.com, tel: +90 505 7958124, +90 2167730616 phone: +90 505 7958124, +90 2167730616 
alındığında; toplumsal bütünleşmenin önemine ve sosyal benliğe ( töre ve kültüre ) sadık kalınmasına sıklıkla vurgu yapıldığı görülmektedir. Bu durumun Türk milletinin varlı̆̆ için hayati önem taşıdığı belirtilmektedir. Aynı zamanda milletin varlığını muhafaza etmesi ve sürdürebilmesi için birinci vazife olarak görülmektedir. Sosyal anlamda birlik ve bütünlüğün merkezinde ise millet olma bilinci işlenmiştir. Geniş mânâda bu bilincin vücut bulduğu, bütünleştiği yer ise devlet müessesesidir.

Orhun Yazıtları'nın söz varlığı olarak deyimler, atasözleri, ikilemeler, koşutluk yönü itibariyle oldukça zengindir. Koşutluk, yazıtların yazı dilinin ve üslûbunun karakteristik özelliğidir. Birleşik sıra cümleleri ile eşit ögeli birimlerden oluşan cümle ifadeleri, anlatıma güzel bir ahenk katar; edebî sanatlar, benzetmeler yönü itibariyle de yazıtların dili zengindir. Derinlikli arka planda dil ve kültürün şekillendiği görülür, aynı zamanda toplumun millı̂ duruşunu etkilediği görülmüştür. Çalışma sonucunda yazıtlarda geçen atasözü ve deyimlerin dönemin söz varlığında önemli bir etkiye sahip olduğu belirlenmiştir. Bu bakımdan Türkçe en az üç bin yıllık bir geçmişi olan işlenmiş bir dil hüviyeti ile karşımıza çıkmaktadır.

Yazıtlarda dilin ve sözün ifade zenginliğinde kullanılan gerek atasözleri gerekse deyimlerin anlam içerikleri, Türklerin iç dünyasını öğrenme fırsatı vermektedir. Bu bakımdan Türk milletinin, karakteristik özellikleri bakımından bozkırda özgürlükçü bir ruh dünyasına sahip olduğu, zaman zaman Kağan'ın sözünü dinlemez oluşu, disiplin altında tutulması güç bir toplumsal psikolojiye sahip olduğu kanaatini uyandırmaktadır.

Bununla birlikte Orhun Yazıtları'nda geçen atasözü ve deyimlerde Kağan'ın milletine karşı olan görev ve sorumluluklarına sık sık vurgu yapılmakla birlikte, milletin de Kağan'a karşı olan görev sorumluluklarının olduğu ifade edilir. Kağan'ın millete olan düşkünlüğü, milletin adının sanın yok olmaması için var gücüyle çalışması, gereken fedakârlı̆̆ı yapması ve böylece devleti ve milleti için savaşan "alp insan" tipinin sosyolojik anlamda varlığının ortaya çıkması anlatılır. Türk boylarında millet olma şuurunun oluşması ile töreye ve kağana biat eden farklı isimlerdeki akraba boylarının Türk ismi ile bir araya getirilip millet bilincinin oluşturulması dil ve kültür birlikteliği kapsamında işlenmiştir.

Türklerin inanç dünyasından ve Gök Tanrı inancından söz edilmiştir. Kağan’ın Gök Tanrı'dan "kut” alması kutlu olması, yazıtlarda işlenen kültürel boyutta mitolojik unsurlar arasındadır. Vefat edenlerin ruhunun uçması göğe yükselmesi ile vefat eden kişinin arkasından yas tutulması, ağıt yakılması yine inanç kültürü kapsamında bahsedilmiştir. Çin kültürüne özenmenin Çin inanç sistemi olan Budizm’i benimsemenin Türk Milletinin Çin kültürü içerisinde erimesine, yok olmasına neden olacağı vurgulanmıştır. Bu durumdan korunmanın yolu ise millî şuurun oluşturulmasına bağlı olduğu dikkat çekilmiştir.

Bununla birlikte; tehlike büyümeden önlenmesi, yllanın başının küçük iken ezilmesi, devletin ve milletin var olmasındaki önem, Türk kültüründe örgütlenmenin ve devlet sahibi olmanın önemi, devletin bekası ve Türk boylarının bir arada tutulması, devleti ve milleti için savaşan "alp insan" tipinin sosyolojik anlamda varlığının bulunması yazıtlarda geçen atasözü ve deyimlerde işlenen konular arasındadır.

Yazıtlarda sıklıkla Türk boyları arasında birlik ve bütünlüğün sağlanmasına ve Kağan'ın önderliğinde düşmanlara karşı gücün birleştirilmesine dikkat çekilmiştir. Türk devlet geleneğinde "il tutmak ve töreyi yürütmek" ifadesinin anlamı kapsamında devlet ile kanunun bir arada yürütülmesi kültürel boyutta yazıtlarda işlenen konulardandır. Yani devleti devam ettirmenin yolunun törenin kanunun tatbik edilmesidir. Devlet (il tutmak) varsa töre vardır. Devlet sahibi olmanın memleket sahibi olmanın

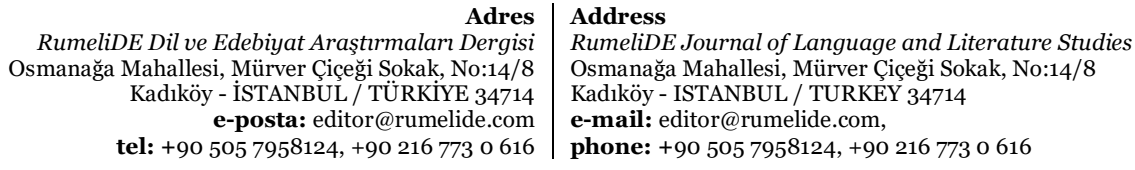


önemine sıklıkla vurgu yapılmıştır. Bununla birlikte yazıtlarda geçen atasözleri ve deyimlerin verdiği mesajlar, millî kimliğin oluşmasında da önemli rol oynamıştır.

\section{Kaynakça}

Ata, A. (2011). Orhun Türkçesi. T.C. Anadolu Üniversitesi Yayını No:2347.

Atasözleri ve Deyimler Sözlüğü. (2009). Türk Dil Kurumu. Erişim adresi: http://www.tdk.gov.tr/index.php?option=com_atasozleri\&view=atasozleri.

Aydın E., (2008), “Ongi Yazıtı Üzerine İncelemeler”, İlmi Araştırmalar Dergisi Sayı 25.

Bardakçı V. V., (2018), “Osmanlı Devleti Öncesi Vezirlik” İstem Dergisi Yıl: 16 Sayı:32.

Çay A. M., (2009), “Tarih Türk Tarihi ve Kültürü Tarihte Türk Devlet ve Beylikleri (Türkiye Dışl)”, T.C. Kültür ve Turizm Bakanlığı Türkiye Kültür Portalı Projesi, Ankara.

Demir, S. T., (2017), “ Türk Toplumunun Kültürel Belleği Bağlamında Orhun Abideleri'ni Yeniden Düşünmek: Taşın Bedeni ve Belleği ”, Journal of History Culture and Art Research, 6(2), 422440. doi:http://dx.doi.org/10.7596/taksad.v6i2.580.

Demirbilek, S. (2016). Orhon Yazitlarında Geçen t(e)Đri töp(ü)sinte tut(u)p yüg(e)rü kötürm(i)ş İbaresi Üzerine. Dede Korkut, Aralık 2016/11: 47-52.

Derin, S. (2014). Göktürk Kitabelerinde Türk Dini İnancın İzleri.Turkish Studies - International Periodical For The Languages, Literature and History of Turkish or Turkic Volume 9/9 Summer 2014, p. 465-474, Ankara-Turkey.

Elçin, Ş. (2004). Halk Edebiyatına Giriş. Ankara: Akçağ.

Emiroğlu, S. (2011), Orhun Abidelerindeki Tamlamaların Türkiye Türkçesindeki Kullanımı, 1st International Conference on Foreign Language Teaching and Applied Linguistics, May 5-7, Sarajevo.

Enginün, İ. (2010). Orhun Yazttlart:Besleyici Güç. Orhon Yazttlarının Bulunuşundan 120 Yll Sonra Türklük Bilimi ve 21. Yüzyıl 3. Uluslararası Türkiyat Araştırmaları Sempozyumunda sunulmuş bildiri. Hacettepe, Ankara.

Kaplan, M. (1985).Orhun Abidelerinde Mekân-İnsan Münasebeti. Türklük Araşttrmaları,1, 1-6.

Koçak, K. (2011), İslamiyet’ten Önceki Türk Devlet Geleneklerine Göre Tahta Çıkma Töreni ve Yöntemleri, Gümüşhane Üniversitesi Sosyal Bilimler Elektronik Dergisi, Sayı 4, Haziran, 101117.

Kuljanova, B. (2010). Eski Türk Anıtlarındaki Halk Birliği ve Memleket Bütünlüğü Ülküsü («Orhon» ve «Kutadgu Bilig» Eserlerine Göre). Orhon Yazıtlarının Bulunuşundan 120 Yll Sonra Türklük Bilimi ve 21. Yüzyl. 3. Uluslararası Türkiyat Araştırmaları Sempozyumu. Hacettepe, Ankara.

Kumru, C. (2017). Türk Mitoloji Penceresinden Orhun Abidelerine Dair Değerlendirmeler. ulakbilge, 6 (20), s.17-27.

Mert, O. ; Bozkırlı, K., (2015), “Orhun Yazıtları'nda Boyları Bir Araya Getirme Çabaları", Uluslararası Türkçe Edebiyat Kültür Eğitim Dergisi, Sayı: 4/1,sf. 1-15.

Mert, O. (2009). Ötüken Uygur Dönemi Yazıtlarından Tes - Tariat - Şine Us. Ankara: Belen Yayınları.

Orhan, S, ; Gedik, M. ; Bulut, M. (2012), Orhun Abideleri ile Gençliğe Hitabe'nin Sundukları Mesajlar Açısından Mukayesesi Üzerine Bir İnceleme. The Journal of Academic Social Science Studies, S. 908-90.

Tanyeri, Y. (2011), Göktürk Yazısı ve Orhun Türkçesi (Ses ve Biçim Bilgisi, Örnek Metinler, Sözlük), 1. Baskı, Boğaziçi Yayınları, İstanbul.

Taşağıl, A. (2014), Kök Tengri’nin Çocukları: (Avrasya Bozkırlarında İslam Öncesi Türk Tarihi), 4. Baskı, Bilge Kültür Sanat, İstanbul.

Tekin, T. (1998). Orhon Yazttları. İstanbul: Simurg.

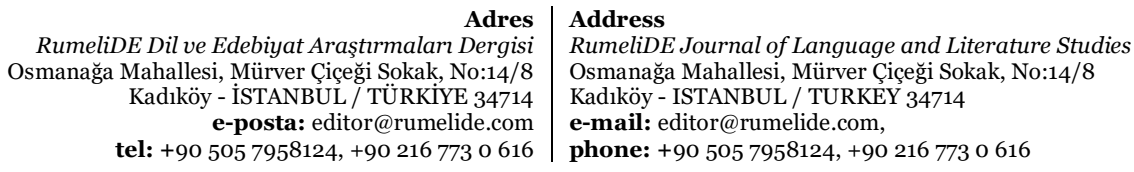


322 / RumeliDE Journal of Language and Literature Studies 2021.25 (December)

Evaluating the messages of the proverbs and idioms in Orhon Inscriptions in regards to language and culture synergy / Y. Girgin (pp. 308-322)

Topsakal, C. (2018), Orhun Yazıtlarının Eğitim Bilimleri Açısından İncelenmesi. Recep Tayyip Erdoğan Üniversitesi Sosyal Bilimler Dergisi (2018) 8: 296-312.

Türkmen, F. (2013), Kök-Türk Abidelerinde Milli Kimlik Hassasiyeti, Milli Folklor, Yıl 25, Sayı 97, 3138.

Yıldırım, D. (1998). Türk Bitiği. Ankara: Akçă̆. 